\title{
8 \\ New GDP Series and Earlier Estimates for the Pre-national Accounts Era
}

How do the new GDP series compare to earlier estimates? ${ }^{1}$ Let us examine them first. Unlike contemporaries who were interested in assessing national income levels, early Spanish research has been concerned with trends and fluctuations in real output and expenditure. ${ }^{2}$ All available GDP estimates are output indices constructed with a fixed, single benchmark level whose economic significance tends to decline as one moves away from the base year. ${ }^{3}$ Moreover, trends in real gross value added are proxied by production indices, which imply the unlikely assumption that total output and input consumption evolve in the same direction and with the same intensity. ${ }^{4}$ Three types of yearly GDP estimates can be distinguished: official estimates by the Consejo de Economía Nacional, its revisions and extensions, and independent estimates.

L. Prados de la Escosura, Spanish Economic Growth, 1850-2015,

Palgrave Studies in Economic History, DOI 10.1007/978-3-319-58042-5_8 


\subsection{Consejo de Economía Nacional Estimates}

In 1944, the Consejo de Economía Nacional or National Economic Council (CEN, thereafter) was asked to estimate a set of national accounts for Spain (CEN 1945, 1965). Three were the main targets: to provide income figures for the years prior to the Civil War (1936-1939), to evaluate 1940 GDP on the available, fragile statistical basis, and to design a direct method to estimate national income for the years to come (Schwartz 1977: 460).

Dearth of data forced CEN to split output indices into two segments with 1929 as the link year. In each case, independent production indices for agriculture and industry were obtained, from which an aggregate index was derived to approximate national income. No regard was paid to services and was implicitly assumed that output in services evolved as a weighted average of agricultural and industrial production.

For the earlier period, 1906-1929, an agricultural output index was built up on the basis of eleven products, mostly dry farming crops (while no livestock output was included), representing half the value of total output. The index of industrial production included eighteen products, rendering a good coverage for mining, but insufficient for manufacturing and construction. Output indices were obtained for agriculture and industry by weighting each single product with its average price over 1913-1928, and the aggregate results were expressed by taking the average for 1906-1930 as 100 .

The composition of agricultural and industrial indices changed from 1929 onwards. Thirteen new crops were added to the agricultural index, distributed into eight main groups of products, that reached up to $80 \%$ of total production, while the industrial index's coverage rose to 38 products distributed into ten different groups. ${ }^{5}$ To derive output indices for agriculture and industry, quantities were weighted by 1929 farm-gate prices and unit value added, respectively. ${ }^{6}$ Improvements in data coverage took place in the 1950 s, but the method remained practically unaltered until 1956. 
An index of total production was obtained by combining agricultural and industrial indices with fixed weights (0.6 and 0.4, respectively, over 1906-1929, and 0.5 each, thereafter). In addition, to allow for short-term fluctuations over the period 1906-1935, a de-trended nuptiality index was combined with the total production index. Nuptiality was excluded after the Civil War (1936-1939) as unsuitable for post-war cycles.

In a second stage, the total production index was linked to an estimate of national income for 1923 in order to derive national income at constant prices. ${ }^{7}$ A further step was to obtain national income figures at current prices by reflating real income with a wholesale price index. Finally, for the years 1957-1964, CEN computed national income directly.

\subsection{Revisions and Extensions of CEN Estimates}

Modern national accounts constructed according to OECD rules are available in Spain since 1954. Attempts to extend them backwards led to revisions of CEN figures that, occasionally, were expanded to cover the expenditure side. Three estimates are worth mentioning.

\subsubsection{Comisaría del Plan de Desarrollo}

A first attempt to revise CEN's estimates was carried out by Comisaría del Plan de Desarrollo, the Development Planning Authority (CPD, thereafter), and covered the period 1942-1954 (CPD 1972). ${ }^{8}$ CPD economists were concerned with the high volatility shown by CEN figures that they attributed to its high dependence on agricultural output and to the exclusion of services. The alternative proposed by CPD was to construct a new index of aggregate performance in which services were added to CEN's indices of agricultural and industrial output. Services output was obtained by combining series on transport and communications and banking. ${ }^{9}$ A real product index was calculated by weighting each sectoral index with the shares of agriculture, industry and services in 
1954 GDP at factor cost, as established in official national accounts (CNE58). ${ }^{10}$ GDP at constant prices for 1942-1953 was, then, derived through backward extrapolation of the 1954 GDP level with the real product index. GDP at current prices was computed, in turn, by reflating real output with a composite index of wholesale prices $(0.3)$ and the cost-of-living index $(0.7){ }^{11}$

GDP was completed with a breakdown of its expenditure components that included direct estimates of investment, public consumption and net exports of goods and services. To approximate private non-residential fixed capital formation, a physical index of private investment was built up by combining, with 1954 weights (CNE58), steel and cement output, machinery imports, electric power and registered transport vehicles. An index of residential investment was proxied by the number of completed dwellings. Public investment, in turn, resulted from adding up investment in agriculture and public works and provincial and local public investment, deflated by a wholesale price index. Levels of each type of investment for 1954 were taken from the national accounts and projected backwards with each investment index to derive real capital formation series and, then, reflated with price indices for production goods and construction materials. Total expenditure of public administration (central, provincial and local governments) re-scaled to match national accounts was used for public consumption and, then, deflated with a wholesale price index. Net exports of goods (at current and constant prices) were used as a proxy for net exports of goods and services, except in the case of tourism, in which the number of tourists (and the cost of living index as deflator) was accepted. Private consumption was obtained as a residual from GDP at market prices (derived by adding indirect taxes net of subsidies to GDP at factor cost, obtained through the production approach) and the directly estimated components of expenditure.

\subsubsection{Alcaide}

A revision of CEN series was also attempted by Julio Alcaide, a pioneer of Spanish national accounts, who, concerned for its volatility and cyclical behaviour, attempted to smoothing CEN's real output (Alcaide 
1976). ${ }^{12}$ For the period 1901-1935, Alcaide derived an index of domestic production by combining, with 1906 fixed weights, CEN indices for agricultural and industrial output, and total employment in services, as a proxy for its output. ${ }^{13}$ GDP at current prices was obtained by reflating real output with a wholesale price index. ${ }^{14}$

\subsubsection{Naredo}

An apparent inconsistency in the CEN series that would have led to underestimating national income for the post-Civil War years motivated José Manuel Naredo's revision of CEN's national accounts (Naredo 1991). The rationale for the under-registration of economic activity in official national accounts lies in the response of economic agents to systematic regulation and intervention of markets under Francoist autarchy. ${ }^{15} \mathrm{He}$ also noticed that CEN's implicit income-elasticity of demand for imports in the 1940s was too low. Naredo proposed, then, an alternative real GDP series for 1920-1950 based upon the revision of official national account estimates by hypothesizing higher incomeelasticity of the demand for imports in the 1940s and by assuming a $10 \%$ fall in GDP resulting from the Spanish Civil War (1936-1939).

\subsection{Independent Estimates}

\subsubsection{Información Comercial Española}

The contribution by the research unit of the Ministry of Commerce and published in its journal, Información Comercial Española (ICE, thereafter), represented a major improvement over earlier indices of Spanish aggregate performance (ICE 1962). ${ }^{16}$ The 'general index of total production', as its authors named it, covered 1951-1960 and represented a Laspeyres volume index in which three major sectors, agriculture and fishing, mining, manufacturing and construction, and trade and services, were combined with 1958 gross value added as weights. For each sector, a Laspeyres volume index with 1958 weights was constructed, in which 
four branches were included for agriculture, sixteen for industry, and six for services, the latter appearing for the first time in pre-national accounts GDP estimates. ${ }^{17}$

Real product series was complemented with a quantity index for investment based on construction and public works, afforestation and the consumption (production plus imports) of machinery and equipment.

\subsubsection{Schwartz}

A major attempt at overcoming CEN's estimates for the period 19401960 was carried out by Pedro Schwartz, at the Bank of Spain's research unit, where he assembled new empirical evidence and used transparent methods in which indirect methods and regression analysis were combined (Schwartz 1976). In the new series, gross value added for every major sector in the economy was obtained by regressing their value-added levels (derived from official national accounts) on a set of indicators over 1954-1960, and the resulting structural relationship was applied to the set of variables or indicators to compute sectoral value added for the earlier pre-national accounts period 1940-1953. Gross domestic product (nominal and real) was derived by aggregation. ${ }^{18}$

\subsubsection{Carreras}

The most ambitious attempt to derive historical series of real GDP was produced by Albert Carreras (1985) who built up an index from the demand side, covering a longer time span, $1849-1958 .{ }^{19}$ Weights for the main aggregates (private and public consumption, investment, net exports) were derived from the 1958 benchmark from the national accounts, while the 1958 input-output table allowed the breakdown of each series into its main components. ${ }^{20}$

However, a few shortcomings can be observed in an otherwise major piece of research. For example, the consumption series only cover food, beverages and tobacco, and clothing while services are neglected. ${ }^{21}$ Actually, it could be argued that consumption growth may be possibly biased downwards since the goods included in the series (food and 
clothing) are those of lower income-elasticity of demand. ${ }^{22}$ In addition, the use of end-year (1958) fixed weights could underestimate GDP growth since relative prices for capital goods, the fastest growing component of expenditure, declined over time rendering, hence, a lower weight for investment than would have been the case if relative prices of any previous year were used. ${ }^{23}$

\subsection{Comparing the New and Earlier GDP Estimates}

How does the new GDP series compare to the earlier estimates? There is a significant agreement about performance over the long run between Carreras estimates and my new series, although significant discrepancies emerge in the short term. During the first half of the twentieth century, the new GDP series present slower growth than those by Alcaide and CEN (Fig. 8.1).

When the focus is placed on specific periods, the variance across different estimates emerges. World War I years seem to have been of fast

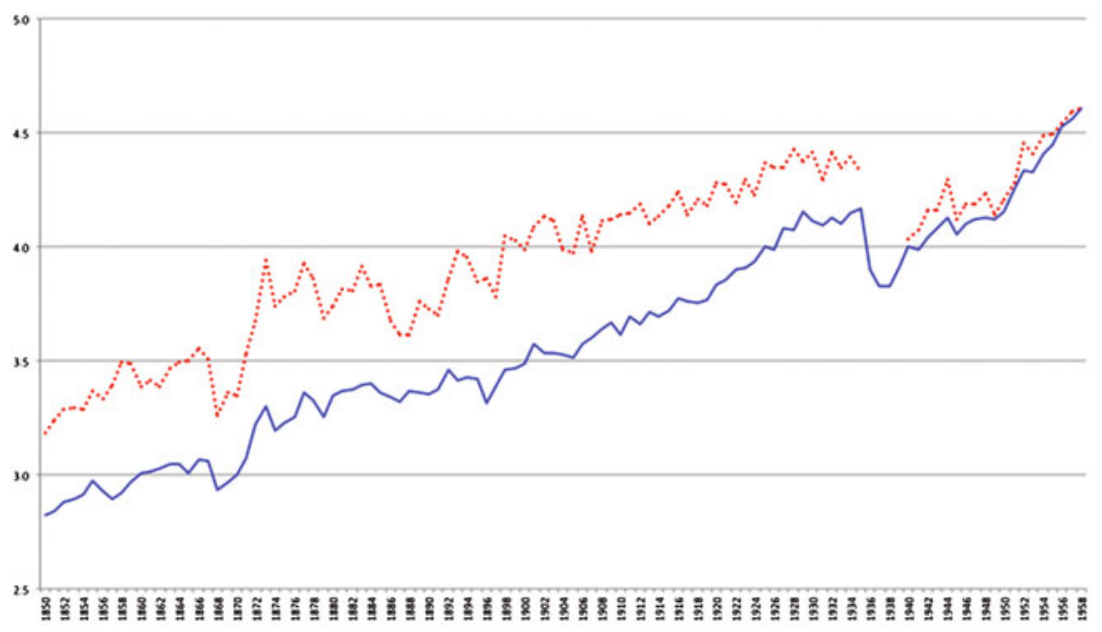

Fig. 8.1 Alternative real GDP estimates, 1850-1958 (1958 = 100) (logs) 
growth (CEN, Alcaide and Carreras), in which the economy would have taken advantage of Spain's neutrality to cater for the needs of belligerent nations while domestic industry expanded on the basis of import substitution. This conventional depiction is challenged by the new GDP series. Then, the post-war years and especially the 1920s exhibit accelerated growth in CEN and Alcaide's. estimates while Carreras' suggest deceleration. The new GDP series provide an even more optimistic picture than Alcaide's.

The impact of Great Depression in Spain (1929-1933) varies dramatically according to different authors. Spain's economy decelerated but continued growing in Alcaide's view, stagnated in Naredo's, mildly contracted in Carreras' computations and definitely shrank in CEN's estimates. The new series side along CEN's but with a less intense decline.

Earlier estimates are discontinued between 1936 and 1939, so comparing output levels in 1935 and 1940 is the only way to assessing the impact of the Civil War (Fig. 8.2). A consensus exists about a substantial contraction in economic activity during the war years, around $6 \%$ per annum, but for Naredo's mild $-2.1 \%$. In my new estimates, the Civil War represented a milder but still deeper shrinkage than Naredo's. ${ }^{24}$

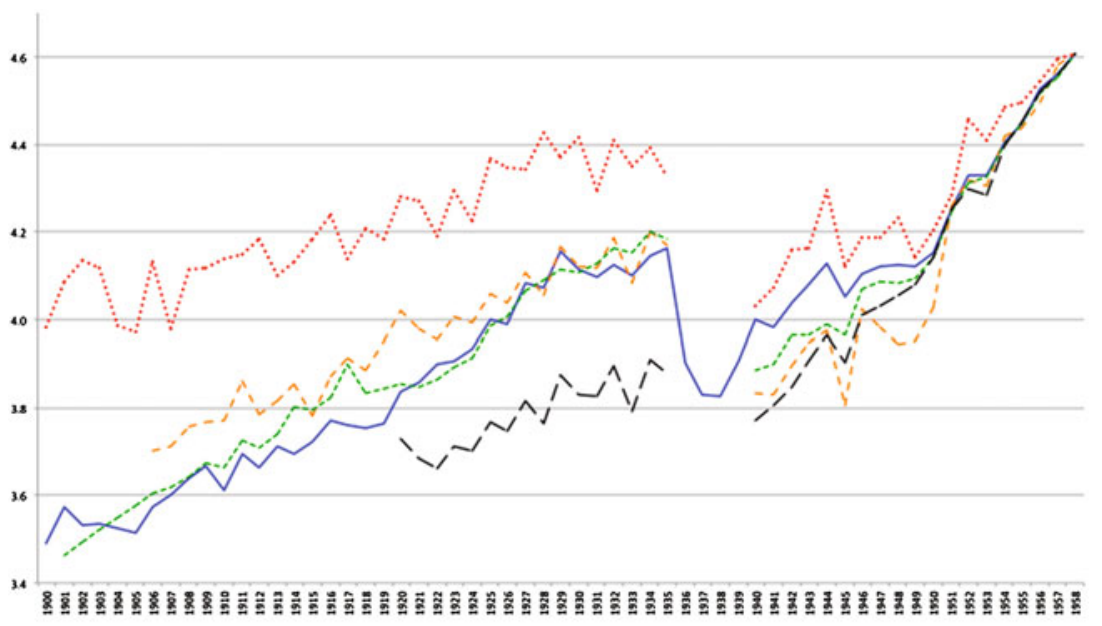

Fig. 8.2 Alternative real GDP estimates, 1900-1958 (1958 = 100) (logs) 
Table 8.1 Real GDP growth in the pre-national accounts era: alternative estimates, 1850-1958 (\%)

\begin{tabular}{lrccccccc}
\hline & CEN & CPD & Alcaide & Naredo & ICE & Schwartz & Carreras & New series \\
\hline $1850-1958$ & & & & & & & 1.7 & 1.7 \\
$1901-1958$ & 2.6 & & 2.8 & & & & 1.6 & 1.8 \\
$1850-1883$ & & & & & & & 2.2 & 1.7 \\
$1883-1913$ & & & & & & 0.6 & 1.1 \\
$1901-1913$ & 1.6 & & 2.3 & & & 0.1 & 1.2 \\
$1913-1918$ & 1.4 & & 1.9 & & & 2.2 & 0.3 \\
$1918-1929$ & 2.5 & & 2.6 & 1.6 & & & 1.5 & 3.9 \\
$1929-1933$ & -2.1 & & 1.0 & -2.1 & & & -0.6 & -1.5 \\
$1933-1935$ & 4.3 & & 1.5 & 4.3 & & & -1.1 & 3.0 \\
$1935-1940$ & -6.7 & & -6.0 & -2.1 & & & -5.9 & -3.5 \\
$1940-1944$ & 3.6 & 0.7 & 2.6 & 4.8 & & 2.6 & 6.5 & 4.0 \\
$1944-1950$ & 0.8 & 2.8 & 2.5 & 2.9 & & 0.6 & -1.5 & 0.2 \\
$1950-1958$ & 7.2 & 6.2 & 5.8 & 5.8 & 5.1 & 6.0 & 5.0 & 5.8 \\
\hline
\end{tabular}

Note 'New Series' are GDP estimates at market prices. Sources New Series, see the text. CEN (1945, 1965), ICE (1962), CPD (1972), Alcaide (1976), Naredo (1991), Schwartz (1976), and Carrerras (1985)

The post-war recovery was mild (but for Carreras and Naredo estimates) and short-lived (CEN, Carreras and Schwartz), and only resumed at a fast pace in the 1950s (except for Alcaide) (Table 8.1). The new GDP estimates concur with the view of a post-Civil War mild and long recovery, which makes Spanish post-war experience different from western Europe's fast return to pre-war output levels (Maddison 2010).

\section{Notes}

1. Attempts to provide historical GDP at benchmark years have been carried out by economic historians. Bairoch (1976) and Crafts (1983, 1984) included Spain in their estimates for the nineteenth century computed along Beckerman and Bacon (1966) indirect approach. Following Deane (1957), Prados de la Escosura (1982) reconstructed Mulhall $(1880,1884,1885,1896)$ figures in a consistent way and derived a set of benchmark estimates for Spanish national income for 1832-1894. In addition, GDP estimates for seven benchmarks over the period 1800-1930 from the industry of origin approach are provided in Prados de la Escosura (1988). 
2. It is worth mentioning Mulhall $(1880,1884,1885,1896)$ estimates of national income for a large number of countries, including Spain, in the late nineteenth century. The main contemporary attempts to derive levels of Spain's national income have been collected in Schwartz (1977). The literature on Italy, where detailed benchmark estimates have been constructed, provides a counterpoint (Rey 1991, 1992, 2000, 2002).

3. Unfortunately, the 1958 GDP benchmark is the earliest available in Spain. New, direct GDP estimates for benchmark years prior to 1958, e.g. 1910 or 1930, years for which population censuses are available, would be required to provide a rigorous check on GDP figures derived by projecting benchmarks backwards with quantity and price indices.

4. The reader should be aware that my own estimates suffered from this bias (see Section III). Actually, only a double deflation procedure for inputs and output would provide a correct alternative. By double deflation is meant independent deflation, with their own price indices, of final production and intermediate inputs, so real value added is obtained as a residual. Cf. Cassing (1996).

5. In order to reduce the downward bias for manufacturing, CEN (1945, 1965) overweighted electricity output.

6. Mining was allocated $22.68 \%$ of total industrial output; utilities (represented by electric energy), 20.96\%; and manufacturing only $56.36 \%$. If the size of the industrial sample (2077 million pesetas) is compared to Banco Urquijo 's estimate of industrial output circa 1924, its coverage represents $25 \%$ of total industrial value added.

7. CEN (1945) used an arithmetic average of Banco Urquijo (1924) and Vandellòs (1925) estimates assuming that were independent from each other. Assessments of CEN (1945) income figures are provided by Guerreiro (1946), Hemberg (1955) and Fuentes Quintana (1958), all reprinted in Schwartz (1977). Hemberg (1955) pioneering computation of income using a production approach showed that there were enough statistical data to carry out a direct estimate of GDP from the supply side.

8. The purpose of CPD estimates was to provide statistical background for the econometric model used in simulations during the third 'plan de desarrollo', an instrument of planification indicatif in the early 1970s.

9. Fixed value-added weights from 1954 National Accounts were accepted.

10. National accounts are named after the benchmark year used for its construction. Thus, CNE58 is Contabilidad Nacional de España with 1958 as the base year. 
11. The weights tried to reflect the relative importance of private consumption $(70 \%)$ and the rest of the demand components of GDP $(30 \%)$.

12. Alcaide carried out another revision of the historical accounts for the period 1901-1985 that did not challenge, however, his earlier findings for real product in the pre-national accounts period (Banco de Bilbao 1986). Nevertheless, nominal levels were revised upwards as the historical series were linked to more recent figures from Banco de Bilbao's own GDP estimates. Alcaide (2000) revised his estimates for the early twentieth century, starting in 1898, and spliced them with Fundación BBV's GDP estimates for 1955-1998 (also Alcaide's own work). Unfortunately, Alcaide neither discusses his methods nor substantiates his arguments with empirical evidence, while no sources are provided.

13. Weights were 0.4 for agriculture, 0.25 for industry and 0.35 for services. Since historical active population figures are only available at census years, either Alcaide interpolated census data or applied participation rates, derived at census intervals, to available yearly figures for total population. Alcaide claimed to having adjusted employment in services 'to accute changes in total production' (Alcaide 1976: 1129). As stressed by Tortella (1987), using employment as a proxy for output implies the assumption of stagnant labour productivity in services.

14. Alcaide's revision of CEN figures for 1940-1954 is also far from clear. He relies on a revision of CEN's real output carried out by Tamames without providing the reference. Moreover, while in the case of GDP only the wholesale price index seems to have been used, it appears that Alcaide reflated real national income with the cost of living and wholesale price indices weighted by the shares of consumption and investment in 1954 national accounts, respectively.

15. Naredo (1991) illustrated his argument by referring to the $26 \%$ increase in agricultural output in a single year (1951), following the abolishment of food rationing, which partially liberalized the domestic market.

16. The first independent attempt to derive national income estimates on an yearly basis was carried out by José Castañeda (1945) who provided an estimate of national expenditure from a sample of indirect taxes and government's monopoly revenues, deflated by a wholesale price index, for the period 1901-1934.

17. Each of the 26 groups of goods and services, defined according to the 1958 input-output table's (TIOE58) classification of economic 
activities, was constructed as a Laspeyres volume index with 1958 weighting. In ICE estimates, the coverage of output was far superior to CEN's, with 227 and 45 basic series for industry and services. For agricultural output (excluding livestock, forestry and fishing, for which 21 basic new series were used), CEN revised index was adopted. Weights applied to agriculture, industry and services to derive the "general index of total production" were $0.2693,0.3200$ and 0.4107 , respectively.

18. An indicator is, according to Balke and Gordon (1989), a time-series variable that is correlated with real product in the time period when real GDP is known, i.e. the post-1954 years.

19. The only precedent of Carreras' demand approach is CPD (1972), but it did not represent an independent estimate.

20. Some objections can be raised to the use of a 1958 benchmark as it comes from an autarchic period in which prices were intervened by government regulation and protection. This is a similar case to those of Italy's 1938 (Bardini et al. 1995:123) and Germany's 1937 (Broadberry, 1997) benchmarks. It can be argued, however, that the 1958 inputoutput table is not only the first one available but also the most detailed Spanish one (207 sectors) to date.

21. Food and clothing represent $70 \%$ of total consumption in the benchmark year 1958 (CNE58). However, the sample of consumption goods used in the construction of the annual index only reaches a coverage of $20 \%$ up to 1928 , and $41 \%$ thereafter, as measured for the 1958 benchmark (Carreras 1985: 38-39, 45). Naredo (1991: 144) claimed that Carreras reliance on García Barbancho's (1960) food consumption data led him to use out-dated, downward biased agricultural output statistics.

22. Income elasticity of demand for housing, durables, personal care, transport, recreation, etc. was significantly higher than for food and clothing in 1958 Spain (Lluch, 1969: 68, 78).

23. Two other objections could also be raised to Carreras' pathbreaking contribution. Government consumption was deflated by a wholesale price index, and not by a consumer price index, a better suited deflator, as wages and salaries constituted its main component, since no comprehensive CPI was available at the time the paper was written. In addition, the trade balance only covers commodities. Carreras used 
official values for exports and imports that exaggerate commodity trade deficit for most of the period up to 1913 (see Sect. 7.3).

24. Actually, my yearly estimates indicate a sharper decline between 1935 and 1938 , at $-11 \%$ per year, followed by a recovery up to 1944 .

\section{References}

Alcaide Inchausti, J. 1976. Una revisión urgente de la serie de renta nacional en el siglo XX. In Datos básicos para la historia financiera de España, 2 vols., 1126-1150. Madrid: Instituto de Estudios Fiscales.

Alcaide Inchausti, J. 1986. Series históricas de las principales macromagnitudes en España. Banco de Bilbao. Informe Económico Anual. Madrid: Banco de Bilbao.

Alcaide Inchausti, J. 2000. La renta nacional de españa y su distribución. Serie años 1898 a 1998. In 1900-2000 Historia de un esfuerzo colectivo, ed. J. Velarde Fuertes, 2 vols., 375-449. Madrid: Planeta.

Bairoch, P. 1976. Europe's Gross National Product: 1800-1975. Journal of European Economic History V 2: 273-340.

Balke, N.S., and R.J. Gordon. 1989. The Estimation of Prewar Gross National Product: Methodology and New Evidence". Journal of Political Economy 97: 38-92.

Bardini, C., A. Carreras, and P. Lains. 1995. The National Accounts for Italy, Spain and Portugal. Scandinavian Economic History Review XLIII 1: $115-146$.

Beckerman, W., and R. Bacon. 1966. International Comparisons of Income Levels: A Suggested New Measure. Economic Journal LXXVI: 516-536.

Broadberry, S.N. 1997. Anglo-German Productivity Differences 1870-1990: A Sectoral Analysis. European Review of Economic History 1 (2): 247-267.

Carreras, A. 1985. Gasto nacional bruto y formación de capital en España, 1849-1958: primer ensayo de estimación. In La Nueva Historia Económica en España, ed. P. Martín Aceña, and L. Prados de la Escosura, 17-51. Madrid: Tecnos.

Cassing, S. 1996. Correctly Measuring Real Value Added. Review of Income and Wealth 42 (2): 195-206.

Castañeda, J. 1945. El consumo de tabaco en España y sus factores. Revista de Economía Politica, I, 1: 195-292. Partially reprinted in P. Schwartz, ed. 
1977. El Producto Nacional de España en el siglo XX, 209-215. Madrid: Instituto de Estudios Fiscales.

Comisaria del Plan de Desarrollo Economico y Social. 1972. Series cronológicas del modelo econométrico, vol. II. Madrid: Presidencia del Gobierno.

Consejo de Economia Nacional. 1945. La Renta Nacional de España, 2 vols. Madrid: C.E.N.

Consejo de Economia Nacional. 1965. La Renta Nacional de España, 1906-1965. Madrid: C.E.N.

Crafts, N.F.R. 1983. Gross National Product in Europe, 1870-1910: Some New Estimates. Explorations in Economic History 20 (4): 387-401.

Crafts, N.F.R. 1984. Patterns of Development in Nineteenth Century Europe. Oxford Economic Papers, XXXVI 4: 438-458.

Deane, P. 1957. Contemporary Estimates of National Income in the Second Half of the Nineteenth Century. Economic History Review IX: 451-461.

Fuentes Quintana, E. 1958. Las estimaciones de la renta nacional de España. In La contabilidad nacional de España (Cuentas y cuadros de 1954), ed. M. De Torres, 13-48. Madrid: Instituto Sancho de Moncada. Reprinted in P. Schwartz (ed.). 1977. El. Producto Nacional de España en el siglo XXInstituto de Estudios Fiscales Madrid 369-422.

Garcia Barbancho, A. 1960. Análisis de la alimentación española. Anales de Economía 66: 72-119 and 67: 271-367.

Guerreiro, A. 1946. A propósito de 'La Renta Nacional en Espańa'. Moneda y Crédito 17: 3-18. Reprinted in P. Schwartz,1977 El Producto Nacional de España en el siglo XX Instituto de Estudios Fiscales Madrid 233-263.

Hemberg, P. 1955. Informe preliminar sobre la renta interior de Espańa. Revista de Economía Política VI (2): 114-171. Reprinted in P. Schwartz, ed. (1977), El Producto Nacional de España en el siglo XX, 265-341. Madrid: Instituto de Estudios Fiscales.

Informacion Comercial Española. 1962. Datos y reflexiones sobre el desarrollo de la economía española. Información Comercial Española 341: 39-97.

Lluch, C. 1969. Elasticidades de Engel y de precios para las grandes categorías de bienes de consumo en España. Moneda y Crédito 108: 47-94.

Maddison, A. 2010. Statistics on world population, GDP and per capita GDP, 1-2008 AD, Horizontal file. http://www.ggdc.net/maddison/.

Mulhall, M.G. 1880. The Progress of the World in Arts, Agriculture, Commerce, Manufactures, Instruction, Railways, and Public Wealth since the Beginning of the Nineteenth Century. London: Edward Stanford. 
Mulhall, M.G. 1884, 1886, 1892, 1899. Dictionary of Statistics. London: Routledge and Sons.

Mulhall, M.G. 1885. History of Prices since the Year 1850. London: Longmans, Green, and Co.

Mulhall, M.G. 1896. Industries and Wealth of Nations. London: Longmans, Green, and Co.

Naredo, J.M. 1991. Crítica y revisión de las series históricas de renta nacional de la postguerra. Información Comercial Español 698: 132-152.

Prados de la Escosura, L. 1982. Comercio exterior y crecimiento económico en España, 1826-1913: tendencias a largo plazo, 7. Madrid: Banco de Espańa, Estudios de Historia Económica no.

Prados de la Escosura, L. 1988. De imperio a nación. Crecimiento y atraso económico en España (1780-1930). Madrid: Alianza.

Rey, G.M. (ed.). 1991. I conti economici dell'Italia. I. Una sintesis dell fonti ufficiali 1890-1970. Roma-Bari: Laterza.

Rey, G.M. (ed.). 1992. I conti economici dell'Italia. II. Una stima del valore aggiunto per il 1911. Roma-Bari: Laterza.

Rey, G.M. (ed.). 2000. I conti economici dell'Italia. III. Il valore aggiunto per gli anni 1891, 1938, 1951. Roma-Bari: Laterza.

Rey, G.M. (ed.). 2002. I conti economici dell'Italia. IV. Il conto risorce e impieghi 1891(1911), 1938, 1951. Roma-Bari: Laterza.

Schwartz, P. 1976. El Producto Interior Bruto de España de 1940 a 1960. In (1977), El Producto Nacional de España en el siglo XX, ed. P. Schwartz, 443-592. Madrid: Instituto de Estudios Fiscales.

Schwartz, ed. 1977. El Producto Nacional de España en el siglo XX, 443-592. Madrid: Instituto de Estudios Fiscales.

Tortella, G. 1987. El sector terciario en España antes de 1936: una nota de escepticismo sobre las estimaciones al uso. Revista de Historia Económica V2: 587-597.

Vandellós, J.A. 1925. La richesse et le revenu de la Péninsule Ibérique. Metron V 4: 151-186.

Urquijo, Banco. 1924. El progreso y la riqueza de España. Madrid: Imprenta de Samarán y Compañía. 
Open Access This chapter is licensed under the terms of the Creative Commons Attribution 4.0 International License (http://creativecommons.org/licenses/by/ $4.0 /$ ), which permits use, sharing, adaptation, distribution and reproduction in any medium or format, as long as you give appropriate credit to the original author(s) and the source, provide a link to the Creative Commons license and indicate if changes were made.

The images or other third party material in this chapter are included in the chapter's Creative Commons license, unless indicated otherwise in a credit line to the material. If material is not included in the chapter's Creative Commons license and your intended use is not permitted by statutory regulation or exceeds the permitted use, you will need to obtain permission directly from the copyright holder. 